\title{
Search for Mycobacterium paratuberculosis DNA in orofacial granulomatosis and oral Crohn's disease tissue by polymerase chain reaction
}

\author{
M P Riggio, J Gibson, A Lennon, D Wray, D G MacDonald
}

\begin{abstract}
Background-Although intestinal Crohn's disease has long been suspected to have a mycobacterial cause, possible mycobacterial involvement in orofacial granulomatosis (OFG) and oral lesions of Crohn's disease has not yet been investigated.

Aims-As the slow growing Mycobacterium paratuberculosis has been implicated in the aetiology of intestinal Crohn's disease, the potential involvement of this mycobacterial species in OFG and oral lesions of Crohn's disease was investigated.

Patients-To attempt detection of the organism in OFG and oral Crohn's disease tissue samples, a polymerase chain reaction (PCR) assay was used on archival formalin fixed, paraffin wax embedded oral tissue sections from 30 patients with OFG, seven with Crohn's disease, and 12 normal controls.

Methods-The PCR assay used was based on primers targeting the $5^{\prime}$ region of the multicopy IS900 DNA insertion element of the $M$ paratuberculosis genome. In order to achieve maximum sensitivity, two rounds of PCR were carried out and amplicons confirmed by Southern blot hybridisation to a digoxigenin labelled IS900 DNA probe.

Results-None of the OFG and oral lesions of Crohn's disease samples were positive for $M$ paratuberculosis and all normal controls were also negative.

Conclusions-These results suggest that $M$ paratuberculosis may not be a major aetiological agent in OFG or oral Crohn's disease lesions, although the use of paraffin wax embedded tissue as opposed to fresh tissue as a sample source could underestimate the true prevalence of the organism.

(Gut 1997; 41: 646-650)
\end{abstract}

Keywords: oral Crohn's disease; Mycobacterium paratuberculosis; orofacial granulomatosis; polymerase chain reaction

It is now widely known that chronic granulomatous transmural inflammation of the gastrointestinal tract was recognised as a clinical entity in 1913 when Dalziel described a chronic intestinal enteritis. ${ }^{1}$ Thereafter, in 1932 Crohn described a regional ileitis distinct from tuberculosis which came to be known as
Crohn's disease. ${ }^{2}$ It has subsequently been demonstrated that Crohn's disease can affect any part of the gastrointestinal tract from mouth to anus. The first report of Crohn's disease affecting the mouth was made by Dudeney in 1969, describing a tag on the buccal mucosa of a 36 year old patient with known Crohn's disease. ${ }^{3}$

Oral lesions are common in patients with proven intestinal Crohn's disease and include lip swelling with and without fissuring, facial swelling, full thickness gingivitis, mucosal tags/ cobblestoning, oral ulceration, and angular cheilitis. ${ }^{4-6}$ These oral lesions may predate bowel symptoms by years. ${ }^{7}$ Various studies have looked at the prevalence of asymptomatic intestinal Crohn's disease in patients presenting with oral lesions and this ranges from 0 to $48 \%{ }^{8}{ }^{9}$

Orofacial granulomatosis (OFG) was a term introduced by Wiesenfeld et $a l^{\beta}$ to describe the entity where patients have oral lesions resembling those of Crohn's disease clinically and histologically but do not have accompanying gastrointestinal abnormalities. The designation of OFG includes patients with granulomatous disease in whom other entities such as Crohn's disease, sarcoidosis, and tuberculosis have been excluded. Some patients with OFG may subsequently develop gut manifestations of Crohn's disease and therefore be recategorised. It has been suggested that OFG may be largely due to a type IV hypersensitivity reaction to various dietary and environmental allergens. ${ }^{10}$

Orofacial lesions with non-caseating granulomata on biopsy may arise in patients with and without intestinal Crohn's disease. The involvement of the mouth in granulomatous inflammatory processes holds exciting potential in terms of ease of access for biopsy and response to treatment. With this in mind, and considering the literature supporting a possible involvement of Mycobacterium paratuberculosis in Crohn's disease, ${ }^{11-14}$ the possibility of $M$ paratuberculosis being involved in the aetiology of OFG and oral lesions of Crohn's disease was investigated.

The polymerase chain reaction (PCR) is a highly sensitive and specific technique which has been successfully used to detect $M$ paratuberculosis DNA in Crohn's disease tissue. ${ }^{11-14}$ In the present study, PCR using primers directed against the multicopy IS900 DNA insertion element of the $M$ paratuberculosis genome ${ }^{15}$ was carried out on DNA extracted from archival paraffin wax embedded tissue sections from 30
Accepted for publication 2 May 1997 
patients with OFG, seven patients with Crohn's disease, and also 12 normal controls. This is the first study to investigate the possible presence of $M$ paratuberculosis DNA in OFG and oral Crohn's disease tissue.

\section{Patients and Methods}

SELECTION OF SAMPLES

The samples used were from the collection processed and held at Glasgow Dental Hospital and School. Samples were paraffin wax sections of oral tissue, which had been examined histopathologically and classified as OFG or oral manifestations of Crohn's disease on the basis of the presence of non-caseating epithelioid cell granulomata. Thirty seven samples were obtained of which 30 were from patients with OFG and seven were from patients with known gut Crohn's disease. In each case the paraffin wax block showing the best demonstration of granulomata was selected for study. Twelve additional samples were from normal control patients. In all cases duplicate samples were obtained from the paraffin wax blocks, cut on two separate occasions.

TISSUE PROCESSING AND DNA EXTRACTION

For each sample to be analysed by PCR, five $10 \mu \mathrm{m}$ sections were cut. The microtome knife blade was thoroughly cleaned between cutting of each different sample with xylene to prevent sample to sample contamination. The paraffin wax sections were placed in $1.5 \mathrm{ml}$ centrifuge tubes and DNA was extracted using a method developed specifically for obtaining mycobacterial DNA from paraffin wax sections as previously described. ${ }^{16}$ Briefly, tissue sections were deparaffinised in xylene, resuspended in $200 \mu \mathrm{l}$ proteinase $\mathrm{K}(200 \mu \mathrm{g} / \mathrm{ml}) / 50 \mathrm{mM}$ Tris$\mathrm{HCl}, \mathrm{pH} 8.3$, and incubated overnight at $37^{\circ} \mathrm{C}$. Samples were frozen in dry ice for one minute, boiled for eight minutes, placed on ice for five minutes, and spun for two minutes to remove insoluble debris. For each PCR reaction, $40 \mu \mathrm{l}$ of the supernatant was used.

PCR PRIMERS

The primers used for PCR (P90+ and P91+) targeted the IS900 DNA insertion element of $M$ paratuberculosis as previously described, ${ }^{17}$ and were similar to primers P90 and P91 used in another study ${ }^{11}$ except that each primer contained an additional six or seven bases at its $5^{\prime}$ end. The primer sequences were 5'-GAA GGGTGTTCGGGGCCGTCGCTTAGG-3' (P90+; IS900 nucleotides 15-41) and 5'GGCGTTGAGGTCGATCGCCCACGTGA C-3' (P91+; IS900 nucleotides 427-401). The expected size of the amplification product using primer pair $\mathrm{P} 90+/ \mathrm{P} 91+$ is 413 base pairs (bp). PCR was also used to generate an internal IS900 probe for use in subsequent Southern blot hybridisation. The sequences of the primers used for probe generation were 5'-CC AGGGACGTCGGGTATGGC-3' (P25; IS900 nucleotides 53-72) and 5'-GGTCGGCCTTA CCGGCGTCC-3' (P26; IS900 nucleotides 281-262), which give an expected amplification product of $229 \mathrm{bp}$.
PCR

PCR was carried out in a total reaction volume of $100 \mu \mathrm{l}$, with conditions essentially as previously described. ${ }^{11}{ }^{17}$ Each PCR consisted of $10 \mu \mathrm{l}$ of extracted DNA and $90 \mu \mathrm{l}$ of PCR reaction mixture comprising $1 \times \mathrm{PCR}$ buffer $\left(10 \mathrm{mM} \mathrm{KCl}, 1.5 \mathrm{mM} \mathrm{MgCl} \mathrm{M}_{2} 1 \%\right.$ Triton $\mathrm{X}-100), 2.0$ units Dynazyme I DNA polymerase (Flowgen Instruments Ltd, Lichfield, UK), $0.2 \mathrm{mM}$ of each of the four deoxynucleotide triphosphates and primers $\mathrm{P} 90+$ and P91+ each at $6 \mathrm{ng} / \mu \mathrm{l}$. The primers were separated from the other components of the reaction mixture by a layer of wax (DynaWax; Flowgen Instruments Ltd). This hot start PCR method improves the specificity and yield of reaction products by preventing the reaction from starting until the wax has melted following the commencement of thermal cycling. PCR was carried out in an OmniGene thermal cycler (Hybaid Ltd, Teddington, UK). The cycling conditions comprised an initial denaturation step at $94^{\circ} \mathrm{C}$ for five minutes, followed by 40 cycles of denaturation at $94^{\circ} \mathrm{C}$ for five minutes, primer annealing at $58^{\circ} \mathrm{C}$ for two minutes, and extension at $72^{\circ} \mathrm{C}$ for three minutes, and a final extension step at $72^{\circ} \mathrm{C}$ for 10 minutes. A second round of PCR was then carried out using identical conditions, except that $5 \mu \mathrm{l}$ of the first round product was used as template.

For generation of the internal 229 bp probe, PCR was set up as described above except that a $\mathrm{MgCl}_{2}$ concentration of $1.0 \mathrm{mM}$ and the primer pair P25/P26 were used in a single round of PCR. Target DNA was 10 ng of plasmid pPN14 which contains the cloned $M$ paratuberculosis IS900 DNA insertion element. After an initial denaturation step at $94^{\circ} \mathrm{C}$ for five minutes, 30 cycles of denaturation at $94^{\circ} \mathrm{C}$ for one minute, annealing of primers at $50^{\circ} \mathrm{C}$ for one minute, and extension at $72^{\circ} \mathrm{C}$ for two minutes were carried out, followed by a final extension step at $72^{\circ} \mathrm{C}$ for 10 minutes. The 229 bp PCR product was purified using the Wizard PCR Preps Purification System (Promega Corporation, Southampton, UK).

SENSITIVITY OF THE PCR ASSAY

The sensitivity of the PCR assay was determined by spiking DNA extracted from paraffin wax sections of OFG, which were PCR negative for $M$ paratuberculosis DNA, with serial 10-fold dilutions of $M$ paratuberculosis DNA in the range $100 \mathrm{pg}$ to $1 \mathrm{fg}$. PCR was carried out as described above.

\section{PCR QUALITY CONTROL}

Several anti-contamination procedures were used when carrying out PCR. Setting up of PCR reactions, thermal cycling, and post-PCR analysis of reaction products was carried out in separate rooms. Pipette filter tips were used at all stages, except when adding template DNA in which case positive displacement tips were used. Positive and negative PCR controls were included with each batch of samples being analysed; the positive control used was $1 \mathrm{pg}$ of $M$ paratuberculosis DNA instead of sample, and the negative control contained sterile molecular biology grade water instead of sample. 
In order to serve as an internal control for the successful isolation of PCR amplifiable DNA from tissue sections, amplification of the $\beta$-haemoglobin gene was carried out for each sample analysed using nested primer PCR as previously described. ${ }^{18}$

AGAROSE GEL ELECTROPHORESIS

PCR reaction products were fractionated by electrophoresis of $20 \mu \mathrm{l}$ aliquots on $2 \%$ agarose gels containing ethidium bromide $(0.5 \mu \mathrm{g} / \mathrm{ml})$ and visualised under ultraviolet (UV) illumination. A 100 bp DNA ladder (Pharmacia Biotech, Milton Keynes, UK) was used as a size marker.

SOUTHERN BLOT HYBRIDISATION

Amplified products were electrophoresed on $2 \%$ agarose gels as described earlier and transferred to positively charged nylon membranes (Boehringer Mannheim, Lewes, UK) by Southern blotting. Briefly, gels were prepared for blotting by soaking in denaturation solution $(0.5 \mathrm{M} \mathrm{NaOH} / 1.5 \mathrm{M} \mathrm{NaCl})$ for $2 \times 20$ minutes followed by soaking in neutralisation solution (0.5 M Tris- $\mathrm{HCl}, \mathrm{pH} 7.4 / 3.0 \mathrm{M} \mathrm{NaCl})$ for $2 \times$ 20 minutes. DNA was transferred to membranes using a capillary transfer blotting unit (Anachem Ltd, Luton, UK) with $20 \times$ SSC (3.0 M NaCl, $0.3 \mathrm{M}$ sodium citrate, $\mathrm{pH}$ 7.0) as transfer buffer. Following transfer, membranes were rinsed in $2 \times$ SSC and DNA immobilised by exposure to an optimal dose of UV energy in a crosslinker (UVC-508; Anachem Ltd).

Membranes were hybridised overnight at $68^{\circ} \mathrm{C}$ with the $229 \mathrm{bp}$ internal IS900 PCR product labelled with digoxigenin (DNA Labelling and Detection Kit; Boehringer Mannheim) at $25 \mathrm{ng} / \mathrm{ml}$ in standard hybridisation buffer ( $5 \times$ SSC, 1\% blocking reagent, $0.1 \%$ N-laurylsarcosine, $0.02 \%$ sodium dodecyl sulphate (SDS)). Membranes were washed at room temperature in $2 \times \mathrm{SSC} / 0.1 \%$ SDS for $2 \times 5$ minutes, and at $68^{\circ} \mathrm{C}$ in $0.1 \times$ SSC $/ 0.1 \%$ SDS for $2 \times 20$ minutes. Immunological detection was carried out according to the manufacturer's instructions using an antidigoxigenin antibody conjugated to alkaline phosphatase and colorimetric detection with 4-nitro blue tetrazolium chloride/5-bromo-4chloro-3-indolyl-phosphate as a colour substrate.

\section{Results}

Duplicate sets of all the samples analysed demonstrated PCR positivity for the $\beta$-haemoglobin gene, as indicated by the amplification of a $165 \mathrm{bp}$ product, after two rounds of PCR using nested primer pairs (data not shown). This indicated that DNA extraction was successful for each tissue sample being analysed and that the extracted DNA was of sufficient purity and free of PCR inhibitors, thus rendering it suitable for use in subsequent PCR analysis.

The sensitivity of the PCR assay following two rounds of amplification was such that $10 \mathrm{fg}$ of $M$ paratuberculosis DNA was detectable by agarose gel electrophoresis (fig 1), which is the equivalent of two mycobacterial genomes.

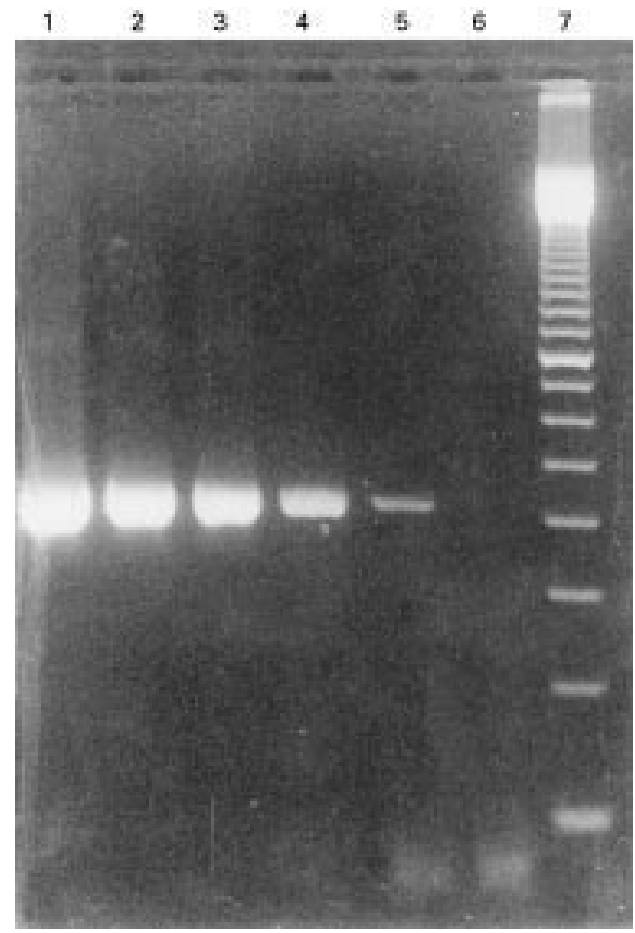

Figure 1: Agarose gel electrophoresis of PCR products (20 $\mu \mathrm{l})$ obtained in the PCR sensitivity assay following two rounds of 40 cycles of amplification with $M$

paratuberculosis IS 900 primers P90+ and P91+. Extracted tissue DNA from PCR negative OFG samples was spiked with serial 10-fold dilutions of $M$ paratuberculosis DNA. Lanes 1-6, M paratuberculosis DNA at 100 pg (lane 1), $10 \mathrm{pg}$ (lane 2), $1 \mathrm{pg}$ (lane 3), $100 \mathrm{fg}$ (lane 4), $10 \mathrm{fg}$ (lane 5), $1 \mathrm{fg}$ (lane 6); lane 7, $100 \mathrm{bp}$ DNA ladder.

$M$ paratuberculosis IS900 PCR was performed on duplicate sets of samples. Following a single round of 40 cycles of PCR using the $M$ paratuberculosis IS900 P90+/P91+ primer pair, all of the samples were negative for the presence of $M$ paratuberculosis DNA both by agarose gel electrophoresis and Southern blot hybridisation, with only the positive control producing a product of $413 \mathrm{bp}$ (data not shown). In order to increase the sensitivity of the assay, a second round of PCR using identical conditions to the first round but with $5 \mu$ of first round product as template was performed. A single OFG sample gave a PCR product, which was slightly smaller in size to that expected for $M$ paratuberculosis positivity (fig 2A). However, this product did not hybridise to the $229 \mathrm{bp}$ IS900 probe in Southern blot hybridisation (fig 2B). No other samples were positive by gel electrophoresis and no samples previously negative by agarose gel electrophoresis following two rounds of PCR demonstrated positivity following Southern blot hybridisation. For each batch of tissue samples being analysed, the $M$ paratuberculosis positive controls were always positive and the negative controls always negative, both by agarose gel electrophoresis and Southern blot hybridisation.

\section{Discussion}

The purpose of this study was to investigate the possibility of mycobacterial involvement in OFG and oral Crohn's disease tissue samples. 
A

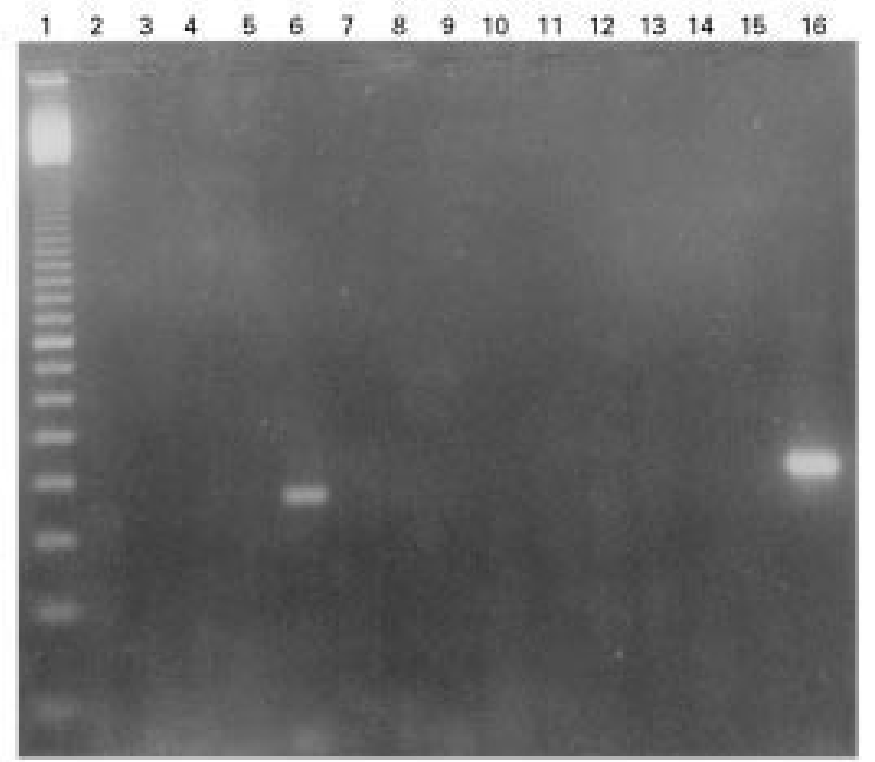

B

1

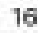

Figure 2: (A) 2\% agarose gel electrophoresis of selected PCR products (20 $\mu \mathrm{l}$ ) obtained from tissue DNA samples following two rounds of 40 cycles of amplification with $M$ paratuberculosis IS900 primers P90+ and P91+. Lane 1, 100 bp DNA ladder; lanes 2-8, OFG samples; lanes 9-11, oral Crohn's disease samples; lanes 12-14, normal samples; lane 15, negative PCR control; lane 16, positive PCR control. The single PCR product obtained from the samples analysed, which is slightly smaller in size than the positive control PCR product, is shown in lane 6. (B) Corresponding Southern blot hybridisation. For orientation of the membrane, lanes 1 and 16 correspond to the $100 \mathrm{bp}$ DNA ladder and PCR positive control lanes, respectively. The PCR product in lane 6 did not hybridise to the probe.

$M$ paratuberculosis is a slow growing organism which has been shown to be the causative agent of Johne's disease, ${ }^{19} 20$ a chronic enteritis of ruminants. Due to the extreme difficulties encountered in attempting to isolate the organism by culture, many investigators have utilised the PCR technique for its detection in diseased tissue. As $M$ paratuberculosis DNA has previously been demonstrated in the intestinal tissue of up to $72 \%$ of patients affected by Crohn's disease by PCR in several studies, ${ }^{11-14}$ it seemed prudent to investigate the possible presence of this mycobacterial species in OFG and oral Crohn's disease tissue. The primers we used for PCR in this study targeted the same $5^{\prime}$ region of the IS900 DNA insertion element of $M$ paratuberculosis as primers previously described. ${ }^{1117}$

The results of our study suggest that in our patient group $M$ paratuberculosis does not appear to be associated with OFG or the oral lesions of Crohn's disease. After two rounds of 40 cycles of PCR followed by Southern blot hybridisation, all tissue samples were found to be negative. The IS900 PCR assay we used was similar to that previously described by Sanderson $e t a l^{11}$ who reported that they could detect as little as $5 \mathrm{fg}$ of $M$ paratuberculosis DNA, which is equivalent to a single mycobacterial genome. We have demonstrated that our assay is of a similar sensitivity with the capability of detecting $10 \mathrm{fg}$ of $M$ paratuberculosis DNA. In view of the fact that we have used a PCR assay that is as sensitive as can reasonably be expected by carrying out two rounds of PCR and Southern blot hybridisation, and no tissue sample was positive for $M$ paratuberculosis DNA it is clear that, at least in the group of patients used in this study, $M$ paratuberculosis DNA is rarely found in OFG and oral Crohn's disease tissue. However, an important consideration is the possibility that some areas of infection within the tissue may be excluded when using paraffin wax sections for DNA extraction and analysis as opposed to homogenates of whole fresh tissue. In other studies, when using paraffin wax embedded tissue sections as a tissue DNA source only 7 to $13 \%$ of samples demonstrated PCR positivity for $M$ paratuberculosis, ${ }^{13}{ }^{14}$ which is in sharp contrast to positivity rates of 46 to $72 \%$ obtained when using fresh tissue for analysis. ${ }^{11-13}$ It is clearly more difficult to detect low abundance $M$ paratuberculosis DNA reliably in paraffin wax samples than when using fresh tissue, as the use of fresh tissue permits the extraction of DNA from a much larger volume of tissue and consequently increases the probability of sampling a discrete focus of infection. It would be most important to extend our study by analysing both paraffin wax embedded and, where possible, fresh tissue from patients with OFG or oral Crohn's disease lesions in several geographical locations in the United Kingdom in order to investigate whether there is an altered distribution of the organism in different patient groups.

The potential involvement of $M$ paratuberculosis in Crohn's disease is a controversial issue. Although some studies have demonstrated the presence of $M$ paratuberculosis DNA in Crohn's disease tissue, ${ }^{11-14}$ PCR negativity for $M$ paratuberculosis DNA has been reported in other studies. ${ }^{21-23}$ Frank and Cook ${ }^{21}$ failed to detect $M$ paratuberculosis DNA in any of 27 Crohn's disease tissue samples examined using nested PCR primers, while the use of a fluorescence PCR method demonstrated negativity in all of 68 Crohn's disease tissue samples analysed. ${ }^{22}$ In a further study, PCR demonstrated the presence of mycobacteria with a similar frequency in the intestinal tissues of patients with Crohn's disease and of normal controls, although no $M$ paratuberculosis DNA was detected in any sample. ${ }^{23}$ PCR negativity for $M$ 
paratuberculosis DNA has also been obtained in tissue samples of sarcoidosis, ${ }^{24}$ which is a generalised granulomatous disease involving multiple organs and which resembles mycobacterial infection histologically. However, the involvement of other mycobacterial species could not be excluded, particularly in view of the fact that Mycobacterium tuberculosis DNA was found in the bronchoalveolar lavage fluid $^{25}$ and spleens ${ }^{26}$ of patients with sarcoidosis in other studies. The potential involvement of other mycobacterial species in OFG and oral lesions of Crohn's disease would undoubtedly be worthy of investigation.

The standard PCR protocols which have previously been used could be further refined by the use of a solid phase hybridisation capture technique, which has recently been developed and applied to PCR detection of $M$ paratuberculosis and $M$ avium subsp. silvaticum. ${ }^{17}$ Solid phase hybridisation capture of mycobacterial DNA from tissue DNA extracts prior to PCR increases sensitivity and substantially eliminates false positives arising due to amplicon contamination. This method should prove valuable in detecting low abundance target DNA sequences in tissue samples, and its application in attempting to identify $M$ paratuberculosis DNA in oral tissue may further clarify the possibility of any aetiological role for this organism in OFG and oral lesions of Crohn's disease.

We thank the Crohn's in Childhood Research Association for their financial support. We are grateful to Professor John Hermon-Taylor for provision of plasmid pPN14.

1 Dalziel TK. Chronic intestinal enteritis. BMF 1913; ii: 1068-70.

2 Crohn BB, Ginzburg L, Oppenheimer GD. Regional ileitis, a pathological and clinical entity. FAMA 1932; 99: 1323-9. 3 Dudeney TP. Crohn's disease of the mouth. Proc R Soc Med 1969; 62: 1237

4 Croft CB, Wilkinson AR. Ulceration of the mouth, pharynx and larynx in Crohn's disease of the intestine. Br F Surg 1972; 59: 249-52.

5 Basu MK, Asquith P, Thompson RA, Cooke WT. Oral manifestations of Crohn's disease. Gut 1975; 16: 249-54.

6 Schiller KFR, Golding PL, Peebles RA, Whitehead J Crohn's disease of the mouth and lips. Gut 1971; 12: 864-5.

7 Ghandour K, Issa M. Oral Crohn's disease with late intestinal manifestations. Oral Surg Oral Med Oral Pathol 1991; 72: $565-7$.
8 Wiesenfeld D, Ferguson MM, Mitchell DN, MacDonald DG, Scully C, Cochran K, et al. Oro-facial granulomatosis-a clinical and pathological analysis. $Q \mathcal{F} \mathrm{Med}$ 1985; 54: 101-13.

9 Editorial. Orofacial granulomatosis. Lancet 1991;338: 20-1.

10 Gibson J, Forsyth A, Milligan KA. Orofacial granulomatosis - the role of patch testing. Br f Dermatol 1995; 133 (suppl 45): 25 .

11 Sanderson JD, Moss MT, Tizard MLV, Hermon-Taylor J. Mycobacterium paratuberculosis DNA in Crohn's disease tissue. Gut 1992; 33: 890-6.

12 Dell'Isola B, Poyart C, Goulet O, Mougenot JF, SadounJourno E, Brousse N, et al. Detection of Mycobacterium paratuberculosis by polymerase chain reaction in children paratuberculosis by polymerase chain reaction in child

13 Lisby G, Andersen J, Engbaek K, Binder V. Mycobacterium paratuberculosis in intestinal tissue from patients with Crohn's disease demonstrated by a nested primer polymerase chain reaction. Scand $\mathcal{F}$ Gastroenterol 1994; 29: 923-9.

14 Fidler HM, Thurrell W, Johnson NMcI, Rook GAW, McFadden JJ. Specific detection of Mycobacterium paratuberculosis DNA associated with granulomatous tissue in Crohn's disease. Gut 1994; 35: 506-10.

15 Green EP, Tizard MLV, Moss MT, Thompson J, Winterbourne DJ, McFadden JJ, et al. Sequence and characteristics of IS900, an insertion element identified in a human Crohn's disease isolate of Mycobacterium paratuberculosis. Nucl Acid Res 1989; 17: 9063-73.

16 Cook SM, Bartos RE, Pierson CL, Frank TS. Detection and characterization of atypical mycobacteria by the polymerase chain reaction. Diagn Mol Pathol 1994; 3: 53-8.

17 Millar DS, Withey SJ, Tizard MLV, Ford JG, HermonTaylor J. Solid-phase hybridization capture of lowabundance target DNA sequences: application to the polymerase chain reaction detection of Mycobacterium paratuberculosis and Mycobacterium avium subsp. silvaticum. Anal Biochem 1995; 226: 325-30.

18 Frank TS, Cook SM, Del Buono EA, Wilson MD. A simplified method for detecting cytomegalovirus by polymerase chain reaction from histologic sections of small biopsies. Mod Pathol 1992; 5: 449-54.

19 Chiodini RJ, van Kruiningen HJ, Merkal RS. Ruminant paratuberculosis (Johne's disease): the current status and future prospects. Cornell Vet 1984; 74: 218-62.

20 Vary PH, Andersen PR, Green E, Hermon-Taylor J, McFadden JJ. Use of highly specific DNA probes and the polymerase chain reaction to detect Mycobacterium paratuberculosis in Johne's disease. $\mathcal{F}$ Clin Microbiol 1990; 28: $933-7$.

21 Frank TS, Cook SM. Analysis of paraffin sections of Crohn's disease for Mycobacterium paratuberculosis using polymerase chain reaction. Mod Pathol 1996; 9: 32-5.

22 Rowbotham DS, Mapstone NP, Trejdosiewicz LK, Howdle PD, Quirke P. Mycobacterium paratuberculosis DNA not detected in Crohn's disease tissue by fluorescent polymerase chain reaction. Gut 1995; 37: 660-7.

23 Dumonceau JM, Vangossum A, Adler M, Fonteyne PA, Vanvooren JP, Deviere J, et al. No Mycobacterium paratuberculosis found in Crohn's disease using the polymerase chain reaction. Dig Dis Sci 1996; 41: 421-6.

24 Lisby G, Milman N, Jacobsen GK. Search for Mycobacterium paratuberculosis DNA in tissue from patients with sarcoidosis by enzymatic gene amplification. APMIS 1993; 101: 876-8.

25 Saboor SA, Johnson NMcI, McFadden JJ. Detection of mycobacterial DNA in sarcoidosis and tuberculosis with mycobacterial DNA in sarcoidosis and tuberculosis
polymerase chain reaction. Lancet 1992; 339: 1012-5.

26 Mitchell IC, Turk JL, Mitchell DN. Detection of mycobacterial rRNA in sarcoidosis with liquid-phase hybridisation. Lancet 1992; 339: 1015-7 